\title{
Szerkesztőségi hírek
}

\section{News from the editors}

doi: 10.24365/ef.v58i2.167

A szerkesztőség örömmel osztja meg tapasztalatát arról, hogy az Egészségfejlesztés folyóirat olvasottsága folyamatosan emelkedik: a havi látogatószám márciusban, a 2017-es első szám megjelenésekor megközelítette a 4700-at, az átlagos napi látogatószám pedig február óta 100 felett jár. [1. ábra]

1. ábra: Az Egészségfejlesztés folyóirat olvasottsági statisztikája, 2016-2017

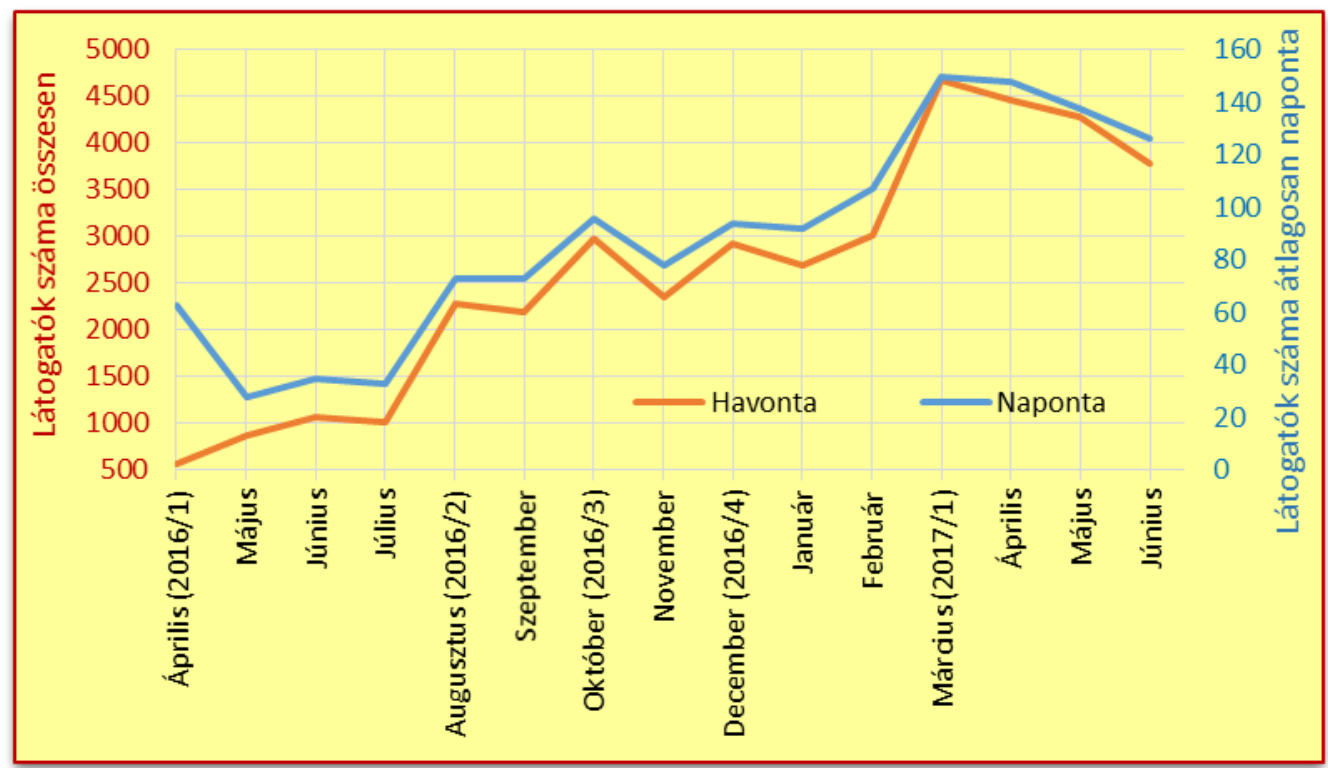

A mennyiségi statisztikai adatok mellett érdekes lehet, hogy milyen témák érdeklik leginkább az olvasókat. A korábbi lapszámokban megjelent 110 írás összefoglalói közül az 5 legnagyobb figyelmet kapó cikket az 1. táblázat tartalmazza.
A legolvasottabb, teljes egészében letöltött közlemények 5-ös listája is figyelemre méltó abból a szempontból, hogy az egészségfejlesztés iránt érdeklődő szakemberek mit találtak leggyakrabban hasznosnak elolvasni. [2. táblázat]

1. táblázat

\begin{tabular}{|c|c|c|c|}
\hline $\begin{array}{l}\text { Megtekintések } \\
\text { száma }\end{array}$ & Közlemény címe & Szerző(k) & Lapszám \\
\hline 336 & $\begin{array}{l}\text { Egészséges életmóddal kapcsolatos kutatások a ha- } \\
\text { zai iskolákban }\end{array}$ & $\begin{array}{l}\text { Járomi É., Szilágyi K., Vitrai } \\
\text { J. }\end{array}$ & 2016/1. szám \\
\hline 215 & $\begin{array}{l}\text { A magyarországi egészségértés nemzetközi össze- } \\
\text { hasonlításban }\end{array}$ & Koltai J., Kun E. & 2016/3. szám \\
\hline 213 & $\begin{array}{l}\text { Egészségkommunikációs Felmérés Eredményei l. - } \\
\text { Felnőtt felmérés }\end{array}$ & Balku E., Vitrai J. & 2016/2. szám \\
\hline 181 & $\underline{\text { Az egészségműveltség definíciói }}$ & Csizmadia P. & 2016/3. szám \\
\hline 172 & $\begin{array}{l}\text { Egészségkommunikációs Felmérés Eredményei II. - } \\
\text { Iskolai felmérés }\end{array}$ & Zsíros E., Balku E., Vitrai J. & 2016/3. szám \\
\hline
\end{tabular}


2. táblázat

\begin{tabular}{|c|c|c|c|}
\hline $\begin{array}{l}\text { Megtekintések } \\
\text { száma }\end{array}$ & Közlemény címe & Szerzö(k) & Lapszám \\
\hline 308 & $\begin{array}{l}\text { A csecsemőkori allergia-megelőzés korszerű irányel- } \\
\text { vei és lehetőségei }\end{array}$ & Réthy L. & 2017/1. szám \\
\hline 169 & $\begin{array}{l}\text { Egészséges életmóddal kapcsolatos kutatások a ha- } \\
\text { zai iskolákban }\end{array}$ & $\begin{array}{l}\text { Járomi É., Szilágyi K., Vitrai } \\
\text { J. }\end{array}$ & 2016/1. szám \\
\hline 127 & $\begin{array}{l}\text { Az iskolai egészségfejlesztés hazai és nemzetközi } \\
\text { szemléletének bemutatatása }\end{array}$ & Járomi É., Vitrai J. & 2017/1. szám \\
\hline 119 & $\begin{array}{l}\text { Beszélgetés a folyóiratról Dr. Surján Orsolya főigaz- } \\
\text { gatóval }\end{array}$ & Kutai O. & 2017/1. szám \\
\hline 114 & $\begin{array}{l}\text { OKOSTÁNYÉR }{ }^{\circledR} \text { - új táplálkozási ajánlás a hazai fel- } \\
\text { nőtt lakosság számára }\end{array}$ & Szücs Zs. & 2016/4. szám \\
\hline
\end{tabular}

A lap szerkesztői remélik, hogy az Egészségfejlesztés legújabb számával sikerül tovább növelni a folyóirat olvasottságát és bővíteni az elért szakemberek körét.

A 2017/2-es lapszám tartalmából ízelítőként:

- Saját vizsgálatuk alapján két szegedi szerző az iskolások táplálkozási szokásainak pszichológiai hátterét vizsgálta, s arra a következtetésre jutottak, hogy a személyiségbeli jellemzők nemcsak a táplálkozási magatartást, hanem az ahhoz kapcsolódó motivációkat is befolyásolják.

- A kultúrának az egészségben és a jóllétben betöltött szerepét elemző és szakpolitikai ajánlásokat megfogalmazó új WHO tanulmány ismertetése mellett a tényekre kíváncsi olvasók számára két friss, a magyarországi egészségügyi rendszer teljesítményét értékelő - a média figyelmét is felkeltő - jelentés összefoglalója kapott helyett ebben a lapszámban. Mindkét jelentés adatai arra engednek következtetni, hogy a hazai egészségügyi rendszer, de különösen a népegészségügy átfogó megújítása nélkül nem közelíthetők a magyar lakosság egészségi mutatói az európai uniós átlaghoz.
- A szakmai munkájuk megalapozásához hasznosnak találhatják a lap olvasói az egyenlőtlenségek „végső" okait feltáró szociológiai elmélet ismertetését, a komplex egészségfejlesztés lehetőségeinek, valamint az egészségfejlesztés gazdasági vonatkozásainak áttekintését. Ezek az írások ráirányítják a figyelmet az egészségfejlesztés korszerű szemléletét meghatározó, jelenlegi szakmai vitákra, támpontot kínálva a hazai gyakorlat frissítéséhez.

- A szokásos „Olvasásra ajánljuk” rovatunkban összegyűjtött, vezető külföldi szaklapokban megjelent cikkek ismertetése mellett hírt adunk egy hazai konferenciáról, amelynek népegészségügyet érintő előadásait az érdeklődők megtekinthetik. Végül egy könyvismertetést ajánlunk a Magyarország jövője iránt érdeklődő olvasók figyelmébe.

A szerkesztőség bízik abban, hogy az olvasói érdeklődés növekedése a jövőben is folytatódik, és minél többen tudják munkájukban hasznosítani az Egészségfejlesztésben olvasottakat. A 2017-es második lapszám változatos cikkeinek közreadásával ehhez kívánunk hozzájárulni. 